\title{
4. The Untranslatable in Philosophy
}

Duncan Large

Jedenfalls ist es ein hermeneutisches Gebot, nicht so sehr über Grade der Übersetzbarkeit, wie über Grade der Unübersetzbarkeit nachzudenken.

(Gadamer 1993, 279)

[In any event it is a hermeneutic imperative to reflect not so much on degrees of translatability as on degrees of untranslatability.]

\section{Approaching Untranslatability}

Untranslatability has always been both a philosophical problem, and a problem for philosophy. It is both a question that philosophy asks of translation (what are the limits of translation?), and a question that translation asks of philosophy (to what extent is philosophy itself translatable?). In the second half of this essay I will broach the second question, the challenge to philosophy posed by questions of translation and translatability, but I will begin by addressing the first, and attempt a definition of untranslatability.

Any attempt to define untranslatability is obliged to map the contours of the translatable, to delimit its furthest extent, and that in turn presupposes a definition of translation itself. 
Untranslatability, then, quickly leads to the heart of translation, indeed some would argue that it is the most urgent question one can ask, for the untranslatable begins where translation (and translatability) ends. Put that way, it sounds as though we are faced with one of those old maps of Africa with a swath of terra incognita marked on it as a heart of blankness (cf. Holmes 1988, 64), or perhaps even an old sea-chart where untranslatability is the monster lying in wait for the unwary in the uncharted waters off the benign, obliging coast of agreed meaning (here be dragons!). In practice, though, the line of demarcation marking the difference between the translatable and the untranslatable, between translation and non-translation, is never that clearcut: things are much messier, for nothing is ever off limits to the translator in this way. In practice, with even the thorniest crux (such as rhymes or wordplay - see Delabastita 1997) it is always possible for a translator to at least make a stab at a translation, and a translator will usually circle round a problematic passage making multiple attempts. Now we are used to thinking of this as a question of gradations along a scale (whether it be a scale of accuracy or adequacy, of equivalence or acceptability), but at what point (if any?) does a difference of degree or quantity (less and less good translations, less and less good approximations to the original) turn into a difference of kind or quality (i.e. not just "that has not been translated well" but "that has not been translated"), and at what point after that does a difference of contingent actuality ("this has or has not been translated") turn into a difference of universal potentiality ("this is translatable or untranslatable")? That is (ultimately) a philosophical decision, but I would suggest that it is not always even arrived at.

In practice the notion of untranslatability is probably most often invoked when a translator despairs of solving a translation problem, and - perhaps dissatisfied with their multiple attempts at a solution - throws up their hands with a cry of "it's impossible to translate!" We 
encounter the notion of untranslatability, then, when an individual translator makes (or, better, tries to make) the move from "I can't translate this" to "This is untranslatable." In other words they extrapolate from a perception of their own individual failure to a structural impossibility. Untranslatability in this sense simply functions as an excuse: it can be invoked by the individual translator from time to time, but it is tantamount to a concession of defeat, and hardly something to be celebrated. The untranslatable functions as a kind of "God of the gaps" (an omnipotent deity invoked in order to shore up any incomplete explanations), and this "God of the gaps" in turn functions as a deus ex machina absolving the translator of their core responsibility, to produce an adequate version. Is that move ever legitimate, or is it always just a reassuring (if self-deluding) cop-out?

Strictly speaking, the question of untranslatability arises only at the point where someone (whether the translator herself or someone else) determines two things: not only, firstly, that the efforts that have been made to translate a passage so far do not constitute a translation - or, in the weak form of the claim, an adequate translation - but also, secondly, that no amount of further effort could ever produce one. Put like that, the impossible extent of the claim that is untranslatability becomes apparent. The concept of untranslatability is an affront to translators (which is why it is routinely resisted). It is premised on the ultimate assessment of translation quality, which is the assessment of whether a passage does or does not deserve to be qualified as a translation at all ("it's not a translation"). Now we are usually loath to make even that first move, to go from "this is a poor translation" to "this is not a translation": practising translators rarely, if ever, describe something as "not a translation"; instead they deal in gradations. But for all that Hans-Georg Gadamer, in my epigraph quotation, writes of "degrees of untranslatability" (Gadamer 1993, 279) - the discourse of untranslatability presupposes a hard- 
and-fast distinction between translation and not-translation, so that untranslatability emerges as a foolish, unworkable term because it conjures up merely a binary opposition rather than a cline. Faced with a particularly tricky translation problem such as a piece of rhymed verse, translators will want to break down the problem into constituent parts and may ultimately conclude that they cannot translate some of these parts, but that is far from asserting that the poem as a whole is untranslatable (let alone that poetry as a genre is untranslatable), and that the version of the poem that results does not count as a translation at all.

We need to come down off our rigorist high horse and acknowledge that the very notion of "untranslatability" is usually used to designate something which cannot be translated adequately or satisfactorily rather than not translated at all (which does not really make any sense). Here is John Sallis offering a milder, more pragmatic definition of untranslatability itself:

there is no poem of which one can say in advance that every would-be translation of it will prove disentitled as such, will prove to be unentitled to be called a translation. If, nonetheless, attestations to the untranslatability of poetry abound, what is attested can only be a more limited untranslatability. In whatever way the attestations are framed, regardless of how unconditionally they may be stated, the untranslatability of poetry thus attested can consist only in poetry's not being translatable without loss and without the flattening and distortion generally that is produced by such loss. (Sallis 2002, 112-13)

On this analysis, then, we never actually mean it when we say something is "untranslatable." It is an empty intensifier on a par with "unbelievable" (which I always cross out in student essays). It 
is meaningless to the practical translator, who will always want to rise to its implicit challenge and will rarely, if ever, want to admit defeat.

In this context one might be forgiven for wondering how the notion of untranslatability even arose in the first place, since we seem to have dismissed the concept before we have even begun discussing it. This approach treats untranslatability as so much metaphysical stuff and nonsense, to be dismissed by a more down-to-earth, common-sensical approach, reminiscent of Dr Johnson dismissing Bishop Berkeley's idealism by kicking a large stone (Boswell 1986, 122). There is something robustly anti-philosophical (detractors would say, unkindly, prephilosophical) about this approach, which dismisses untranslatability as merely one of the nocturnal monsters brought forth unnecessarily by the sleep of reason. If it takes a (nodding) philosopher to even come up with the idea, perhaps untranslatability is merely a dispensable philosophical distraction?

Any theory of untranslatability has to begin by acknowledging that, as Paul Ricœur puts it, "there is translation" (Ricœur 2006, 32), or as George Steiner argues: "We do translate intraand interlingually and have done so since the beginning of human history. The defence of translation has the immense advantage of abundant, vulgar fact" (Steiner 1998, 264). As Anthony Pym and Horst Turk remark, "the key to the debate is the relative looseness with which the concept of translation is used" (Pym and Turk 1998, 276). Untranslatability can always be banished, with a wave of the hand, by the simple expedient of abandoning any hard-line conception of what translation itself is, and instead acknowledging that real-world translation is all about compromise, that translation is a craft, a techne (cf. Biguenet and Schulte 1989), and the no-nonsense translator is an artisan who at the first hint of untranslatability perhaps makes the sign of the cross, but certainly reaches for his trusty tools and gets to work banishing 
untranslatability with every stroke of the pen or touch of the keyboard. This is the picture conjured up by Antoine Berman writing at the end of his magisterial overview of (the untranslatable in) German Romantic translation theory, The Experience of the Foreign:

To be sure, every text is written in a language; and in fact, the multiplicity of terms mentioned, whether it appears in a written or an oral sequence, remains in itself "untranslatable" in the sense that the other language will not have the corresponding terms. But at the level of a work, the problem is not to know whether or not there are equivalents for these terms. Because the level of translatability is different. [...] The alleged untranslatability is dissolved in total translatability [traduisibilité sans reste] by simply having recourse to modes of relation that exist naturally and historically between languages, but adapted in this case to the demands of the translation of a text. (Berman $1992,189[1984,302])$

Berman then details different practical translation strategies - borrowing, neologism, nontranslation, compensation, displacement, homologous replacement - before concluding:

These are not, as one tends to believe, makeshift procedures, but modalities that define the meaning itself of all literary translation, inasmuch as it encounters what is linguistically (and sometimes culturally) untranslatable and dissolves it in actual literary translatability [réelle traduisibilité littéraire] without, of course, slipping into paraphrase or an opaque literalness. (Berman 1992, 189 [1984, 303]) 
For Berman, then, translation is eminently equipped to extend the boundaries of the translatable and reclaim some of that uncharted territory mentioned above, cutting back the teeming undergrowth of "alleged untranslatability" with its machete in the form of a suitable translation strategy. This upbeat conclusion to Berman's study is echoed already by Roman Jakobson in his seminal 1959 article "On Linguistic Aspects of Translation." Here Jakobson peremptorily dismisses what he terms "the dogma of untranslatability," and counters with:

All cognitive experience and its classification is conveyable in any existing language. Whenever there is deficiency, terminology may be qualified and amplified by loan-words or loan-translations, neologisms or semantic shifts, and finally, by circumlocutions. [...] No lack of grammatical device in the language translated into makes impossible a literal translation of the entire conceptual information contained in the original. [...] Any assumption of ineffable or untranslatable cognitive data would be a contradiction in terms. (Jakobson 2012, 128-29)

\section{The Romantic Untranslatable / The Romance of the Untranslatable}

Can untranslatability be quite so easily conjured away, though? As Kirsten Malmkjær has pointed out, in the very same essay where Jakobson apparently argues "all is translatable," he also explicitly claims that "poetry by definition is untranslatable" (Malmkjær 2015, 192). Juliane House also picks up on this contradiction, and counters what she calls Jakobson's “"law of universal translatability" by dwelling on "a few exceptions to universal translatability" (House 2015, 51). She lists three different kinds of exception, namely connotative meanings, "whenever the form of a linguistic unit takes on special importance" (particularly in poetry, and in literary 
translation more generally), and intralinguistic variation (dialect). There is a very slippery slope leading from such piecemeal concessions to untranslatability for specific aspects of texts, to claims of untranslatability for entire text types, such as Jakobson's “poetry by definition is untranslatable." Perhaps, then, we have been a little premature in dismissing untranslatability? Perhaps we have not been describing every possible situation? Perhaps we have just been in denial?

Writing on Schleiermacher's celebrated lecture "On the Different Methods of Translating," Malmkjær points out that his "unquestioning faith in translatability" $(2015,189)$ is associated with what Schleiermacher calls (and loftily dismisses as) "interpreting" (Dolmetschen, the preserve of the business world) rather than "[true] translation" (Übersetzen, pertaining to the areas of scholarship and the arts), which Schleiermacher finds much more problematic and can even lead one to frustrated despair. This despair (Verzweiflung) at ever actualising what one might term, following Kant, the conditions of possibility for "true translation" (die eigentliche Übersetzung) is formulated by Schleiermacher in terms of the hermeneutic imperative to understand the source text author:

If his [the translator's] readers are to understand [verstehen], then they must grasp the genius [Geist] of the language that was native [einheimisch] to the writer, they must be able to observe his characteristic manner of thinking and sensibility [dessen eigenthümliche Denkweise und Sinnesart]; and all he can offer them as a help for achieving these two things is their own language, corresponding in none of its parts to the other tongue, along with himself, as he has recognised his writer now the more, now the less lucidly, and as he admires and applauds the writer's work now more, now less. Does 
not translation appear, viewed in this way, an utterly foolish undertaking [ein thörichtes Unternehmen]? (Schleiermacher 2012, 47 [Störig 1963, 45])

In her reading of this lecture Malmkjær argues that we should characterise Schleiermacher as only a "reluctant Romantic" (Malmkjær 2015, 189), but this concern with the "characteristic" or "peculiar" (eigenthümlich) is itself peculiarly Romantic, and in line with the movement's concern with artistic individuality, idiosyncrasy and genius. In this respect one can readily range Schleiermacher alongside Wilhelm von Humboldt, for example, arguing in 1816 that Aeschylus's Agamemnon is untranslatable “because of its peculiar nature” (Lefevere 1977, 40; “seiner eigenthümlichen Natur nach": Störig 1963, 80), or Schopenhauer arguing in his 1851 essay "On Language and Words": "One cannot translate poems, only transpose them [...] because the foreign language denotes the concept by means of a trope or metaphor which is peculiar to it” (Lefevere 1977, 98-99; “einen ihr eigenthümlichen Tropus, oder Metapher”: Störig $1963,105)$.

In their pessimistic assumptions of untranslatability, philosophising translation in a minor key, these theorists wear their Romanticism on their sleeves in another respect, as well, for such translation theory seems to me to be haunted, and in two senses. On the one hand it is haunted by the prospect of there being some kind of "translation proper" which lies ever elsewhere and does not correspond to the kind of translation one might actually be doing at any one time, and on the other by the conviction that - ironically, paradoxically - such "translation proper" might actually be constituted by untranslatability. This pessimistic, idealist take on translatability proceeds from the recognition that all the translation we do here on earth is somehow tainted; by the mere fact that it pragmatically succeeds it is dismissed as not really translation - what one might call, by 
analogy with the "no true Scotsman fallacy" (Flew 1975, 47), "the no true translation move." Untranslatability haunts the practical translator as a kind of anxiety, so that just as Max Weber's Calvinist is haunted by the fear that he might not number among God's chosen at the end of the day (at the end of days) (Weber 2001, 65), so the Romantic translator is haunted by the idea that "Perhaps my text is untranslatable after all?" That there is a radical, absolute untranslatability out there - an incommensurability between languages and between the humans who speak and use them - which cannot be bridged by practical means. That translation is not only unattainable, but ultimately a category mistake. Such a translator might despair of the very enterprise itself (compare Schleiermacher's black dog of Verzweiflung), and is even potentially paralysed by the effect of (the concept of) untranslatability.

Now untranslatability arrived at from this direction is of a fundamentally different nature to the kind I was describing above. Previously I was approaching the question of untranslatability inductively, from the bottom up - personal experience of translation difficulty, extrapolated - and arguing that it has little currency. As we saw, the extrapolation from personal experience of translation difficulty need not result in a recognition of untranslatability at all, but usually short-circuits the passage into philosophy. By contrast Romantic translation theory arrives at untranslatability not inductively but deductively, from the top down. One is tempted to call this the properly philosophical sense of untranslatability, if that term were not so loaded, since ultimately any conception of “translation proper” (including Jakobson's in 1959) is metaphysical, even mystical. The move from the untranslated to the untranslatable is the transit from empirical observation into abstract philosophy, and the gap between the two is a metaphysical, even theological space (see Apter 2013, 228-46). The last of the great German Romantic translation theorists, Walter Benjamin, will argue that translatability (and, we might 
say, untranslatability) relates to the ontological status of a text and is an inherent property of it (can it be translated in principle?) rather than a contingent feature of the text-in-the-world (whether it has been translated) (Benjamin 2012, 76). Benjamin's is perhaps the most hieratic version of this position, but it pertains to various philosophical traditions, from German Romanticism through to French deconstruction via currents in Anglo-American analytic philosophy of the mid-20th century (cf. Malmkjær in this volume).

\section{Philosophy and the Resistance to Translation}

With the philosophical question of untranslatability still unresolved (is it a meaningful term? is it anything other than a philosophical construct?), let us turn at this point to the second question which I formulated at the outset, the question which translation poses to philosophy (the issue raised by my title, of "The Untranslatable in Philosophy"). For in the perverse beauty contest which is periodically conducted to determine which text type or literary genre might count as the most untranslatable, poetry is not the only winner: also routinely on the podium are scripture (where the notion of untranslatability is ultimately not so much a metaphysical as a theological conception, relating to the ineffable status of the word of God), and, precisely, philosophy. Not least among philosophers, philosophy itself - conceptual language more generally - is often held up as the privileged example of an untranslatable genre: hence Schopenhauer argues, for example (Lefevere 1977, 99-100), that in order to understand concepts in a foreign language one cannot rely on translations and one is really obliged to learn that language, and Heidegger will advance a version of the same argument (De Gennaro 2000). Is there something specific about philosophy, then, which makes it more untranslatable than other text types? More resistant to translation? Perhaps even radically untranslatable? 
The experience of translating two books by Friedrich Nietzsche for Oxford World's Classics (Nietzsche 1998, 2007) has taught me that Nietzsche's late style, while a joy to read in German, poses significant challenges to the translator and might indeed be claimed to operate in some respects at the limits of translatability. When he is not breaking out into actual poetry his prose bears all the hallmarks of a poetic style, bursting with figurative language (as the French philosopher Sarah Kofman explores in Nietzsche and Metaphor, the first book I translated [Kofman 1993]). It is deft, playful and hugely inventive, dazzlingly multilingual and intertextual, rhetorically highly self-aware. These stylistic pyrotechnics are not, of course, specifically philosophical features, and it is as well to note that Nietzsche makes a mockery of any attempt to somehow hive off conceptual language, to set up a prophylactic cordon sanitaire between philosophy and literature in order to argue that conceptual language is peculiarly philosophical and hence peculiarly untranslatable. No, as Nietzsche demonstrates so expertly, when characterising philosophical language one needs to give full force to both terms, for it is philosophy but it is also a language like any other, and susceptible to highly creative manipulation in the hands of a poetic master-craftsman.

When people talk about the specific difficulty (and specific untranslatability) of philosophical language, of course, they usually mean something rather different, namely densely conceptual language à la Kant or Hegel, bristling with technical terms - cruces like aletheia or sophrosyne, Aufhebung or différance. Thankfully (from the point of view of both his readers and his translators), Nietzsche uses remarkably few technical terms, and from my experience of editing The Complete Works of Friedrich Nietzsche for Stanford University Press (Nietzsche 1995- ), the thorniest issue to have come up so far is what to do with the term "Übermensch." The earliest English translations used "superman," as reflected in George Bernard Shaw's play 
Man and Superman (1903), but once Clark Kent had muscled in on the semantic field thirty years later this ceased to be an option. "Overman" was in vogue for a while, as was simply leaving the term untranslated in German. Practical translation projects need practical solutions, though, and the one we have come up with for the Stanford edition (guided by our more overarching concern for inclusive language) is "the superhuman." This solution emerged as a consensus after lengthy e-mail discussions between the two general editors and our two translators of Thus Spoke Zarathustra, Paul S. Loeb and David Tinsley. In similar fashion we have produced a dynamic list of standardised term-translations to which we are still adding from time to time, but which we expect all (currently fourteen) of the translators of our edition to adhere to unless there is good reason to dissent, which they can explain in a note. Such standardisation by fiat is the privilege of editing a project like this, but it is also imperative in the sense that without such agreed principles a standard edition would never be possible.

Before I move on from my experiences with translating and editing Nietzsche, let us note that this kind of practical imperative of translatability is not by any means always imposed on philosophers from without by unsubtle editors. Nietzsche himself published his philological juvenilia in Latin and then translated them into German, and many other philosophers have not only published work in more than one language, but - apparently largely unproblematically published self-translations as a means of promoting their own work and finding a different audience for it, especially in the early modern period with vernacular-language philosophers ensuring that an edition was available in Latin (see Large 2014). Thus Francis Bacon translated his Essays into Latin, assisted by Thomas Hobbes, who also translated his own Leviathan into Latin; Descartes helped his friend Étienne de Courcelles translate his Discours de la méthode into Latin; Spinoza (who otherwise published only in Latin) translated his Short Treatise into 
Dutch. As late as the mid-19th century, Schopenhauer translated his essay on the theory of colours from German into Latin; later on, C. S. Peirce translated some of his early articles into French, while Hannah Arendt translated The Human Condition into German herself, and in our own time some of our most exuberant philosophical translators have been self-translators, notably Quine (self-translating into French and Spanish) and Vilém Flusser. These are not, then, examples of philosophers standing on ceremony and preciously asserting that their concepts are untranslatable; rather, they have unfussily got their hands dirty in the world of practical translation.

\section{"Untranslatables," Translated}

Talking of getting one's hands dirty in the name of philosophical translatability, in the final part of this essay I must turn to a remarkable contemporary project which has done precisely that. I refer, of course, to Barbara Cassin's Dictionary of Untranslatables: this multi-authored volume under Cassin's general editorship first appeared in French in 2004, as Vocabulaire européen des philosophies: Dictionnaire des intraduisibles (Cassin 2004), and an English version duly appeared a decade later, as Dictionary of Untranslatables: A Philosophical Lexicon (Cassin 2014). The preposterous irony of the performative self-contradiction that is a translated "dictionary of untranslatables" has not been lost on anyone (and English is only one of a large number of languages into which it has been translated, or partially translated, from Arabic to Ukrainian). This is a major project in all senses, not just its level of funding, the number of its collaborators, its format and page extent. The original French edition includes contributions from leading philosophers such as Alain Badiou, Etienne Balibar, Françoise Dastur, Monique DavidMénard and Catherine Malabou, while the English edition - edited by a team headed by Emily 
Apter - includes additional material newly commissioned from contributors of the calibre of Judith Butler, Gayatry Chakravorty Spivak and Robert J. C. Young.

Naturally enough, the Dictionary has made many waves since it was first published - and indeed before, given that Cassin was organising "Journées du Vocabulaire européen des philosophies" from a decade earlier (see Cassin 1995). For my purposes in this essay I want to focus in on the understanding and definition of "untranslatables" which guides the project (and which the English version foregrounds, where it was only in the subtitle in the original French). In her Introduction (included in both French and English editions), Cassin describes "untranslatables" as "symptoms of difference" (2014, xvii):

To speak of untranslatables in no way implies that the terms in question, or the expressions, the syntactical or grammatical turns, are not and cannot be translated: the untranslatable is rather what one keeps on (not) translating [l'intraduisible, c'est plutôt ce qu'on ne cesse pas de (ne pas) traduire]. (Cassin 2014, xvii [2004, xvii])

A special sense of "untranslatable" emerges here which I find extremely helpful. It clearly draws on Derrida's understanding of translation as impossible but necessary, caught in a double bind (Davis 2001). But I read the Cassin project's defiant take on translation as an endless process of refinement more in the spirit of Camus (we must imagine the Sisyphean translator happy) or the curiously contorted, vestigial optimism to be found in the work of Samuel Beckett. "Can't translate, must translate," say (adapting the end of The Unnameable), or "Fail again. Fail better" (Worstward Ho). Such an understanding posits translatability as what one might call in Kantian 
vocabulary a regulative idea: in principle unattainable, yet governing one's attempts to approach it from the here-below, always approximately, asymptotically.

\section{Conclusion}

This brings me to my conclusion. Following Cassin, the Franco-German co-editors of a recent collection on untranslatability define the term (in a defiantly bilingual introduction) as "not the symptom of a failure in translation but an event that is constitutive of the act of translating" ("pas le symptôme d'un échec de la traduction mais un événement constitutif de l'acte de traduire" / “nicht das Symptom eines Scheiterns der Übersetzung, sondern ein Ereignis, das für den Akt der Übersetzung konstitutiv ist”: Dünne et al. 2013, 4, 10). And in turn, in a well-known passage from his essay "Plato's Pharmacy" on "the redoubtable, irreducible difficulty of translation," Derrida defines a certain kind of translation ("a violent difficulty in the transference of a nonphilosopheme into a philosopheme") as constitutive of the practice of philosophy itself (Derrida 2004, 77). Translation and philosophy are integrally interwined, and untranslatability is philosophy's gift to translation (in all the ambiguous senses of that word). But if the concept of untranslatability did not exist, would it be necessary to invent it? Louis Kelly strikes at the heart of the debate when he points out: "Whether translation is possible or not, turns on the concept one has of fidelity" (Kelly 1979, 216-17), since fidelity is the standard criterion for evaluations of translation success or failure. And it is precisely for this reason that Lawrence Venuti rejects the very debate over notions of "translatability" and "untranslatability" as vitiated by an "instrumental" conception of translation rather than a "hermeneutic" one (see e.g. Venuti 2017, $5-6)$. 
If one reviews the history of notions of translatability and untranslatability in translation theory, then one is tempted to conclude that it boils down to a question of faith and a matter of temperament, in other words whether one is a "glass half full" or a "glass half empty" kind of person. No prizes for guessing which of those Schopenhauer was, for example, with his positively tragic view of the translator's dilemma, while on the other hand a focus on Quine and Davidson allows Kirsten Malmkjær to subscribe to what one might call the Whig or progressivist view of the history of translation theory, summed up in her claim: "The philosophy of translation shows us that translation is always possible" (Malmkjær 2010, 216). Malmkjær concludes her contribution to this volume by arguing that Jakobson and Davidson act as an antidote to the putatively paralysing effect of the notion of untranslatability, which no longer serves as an obstacle but rather as a "concept of investigation." Other contributions to this volume, similarly, disarm the notion of untranslatability and argue that it should instead be substituted or superseded by a notion of provisionality (Theo Hermans) or indeterminacy (Philip Wilson).

As a practising translator I share in this emerging consensus, but I am also minded not just to let untranslatability go, and to grant it more than a merely historical or heuristic value. Using Cassin I would want translatability to remain a kind of regulative idea, with untranslatability a constant but salutary provocation to the translator so that we are not tempted to repress it in a kind of misplaced triumphalism. For as I was suggesting earlier, when repressed it has an uncanny knack of returning to haunt you. Already in The Translation Zone, Emily Apter warns us against making the simplistic move from "Nothing is Translatable" to "Everything is Translatable" (Apter 2006, 85-93), and her subsequent strictures against the concept of "world literature" have relied on a notion of untranslatability that still has significant purchase (Apter 2013). The German Romantics, I have been suggesting, constituted a concept of untranslatability 
with a powerful sense of peculiarity at its core, and a recognition of this peculiarity is essential to acknowledging the other in their fullest humanity. In this sense untranslatability can be viewed as not a curse but a blessing - it reminds us that translation is always hard, but it lends translation a tragic nobility. It leads the translator not to throw up their hands in despair; instead, it energises and spurs them on to ever more resourceful creative responses.

\section{References}

Apter, Emily. 2006. The Translation Zone: A New Comparative Literature. Princeton, NJ and Oxford: Princeton University Press.

—. 2013. Against World Literature: On the Politics of Untranslatability. London and New York: Verso.

Benjamin, Walter. 2012 [1923]. “The Translator's Task.” Translated by Steven Rendall. In Venuti 2012, 75-83.

Berman, Antoine. 1984. L'épreuve de l'étranger: Culture et traduction dans l'Allemagne romantique. Paris: Gallimard.

—. 1992. The Experience of the Foreign: Culture and Translation in Romantic Germany. Translated by S[tefan] Heyvaert. Albany: SUNY Press. 
Biguenet, John, and Rainer Schulte, eds. 1989. The Craft of Translation. Chicago and London: University of Chicago Press.

Boswell, James. 1986 [1791]. The Life of Samuel Johnson. Edited by Christopher Hibbert. Harmondsworth: Penguin.

Cassin, Barbara, ed. 1995. De l'intraduisible en philosophie. Paris: Albin Michel.

— ed. 2004. Vocabulaire européen des philosophies: Dictionnaire des intraduisibles. Paris: Le Seuil / Le Robert.

—, ed. 2014. Dictionary of Untranslatables: A Philosophical Lexicon. Translated by Steven Rendall et al. Princeton, NJ and Oxford: Princeton University Press.

Davis, Kathleen. 2001. Deconstruction and Translation. Manchester and Northampton, MA: St Jerome.

De Gennaro, Ivo. 2000. "Heidegger on Translation - Translating Heidegger." Phänomenologische Forschungen, Neue Folge 5 (1): 3-22.

Delabastita, Dirk, ed. 1997. Traductio: Essays on Punning and Translation. Manchester: St Jerome; Namur: Presses Universitaires de Namur. 
Derrida, Jacques. 2004. Dissemination. Translated by Barbara Johnson. London and New York: Continuum.

Dünne, Jörg, Martin Jörg Schäfer, Myriam Suchet and Jessica Wilker, eds. 2013. Les Intraduisibles / Unübersetzbarkeiten: Sprachen, Literaturen, Medien, Kulturen / Langues, Littératures, Médias, Cultures. Paris: Editions des Archives Contemporaines.

Flew, Antony. 1975. Thinking About Thinking: Do I Sincerely Want to Be Right? London: Collins Fontana.

Gadamer, Hans-Georg. 1993 [1989]. "Lesen ist wie Übersetzen.” In Gesammelte Werke, vol. 8: 279-85. Tübingen: Mohr.

Holmes, James S. 1988. Translated! Papers on Literary Translation and Translation Studies. 2nd edition. Amsterdam: Rodopi.

House, Juliane. 2015. Translation as Communication Across Languages and Cultures. Abingdon: Routledge.

Jakobson, Roman. 2012 [1959]. “On Linguistic Aspects of Translation.” In Venuti 2012, 126-39.

Kelly, L[ouis] G. 1979. The True Interpreter: A History of Translation Theory and Practice in the West. Oxford: Basil Blackwell. 
Kofman, Sarah. 1993. Nietzsche and Metaphor. Translated by Duncan Large. London: Athlone Press.

Large, Duncan. 2014. “On the Work of Philosopher-Translators.” In Literary Translation: Redrawing the Boundaries, edited by Jean Boase-Beier, Antoinette Fawcett and Philip Wilson, 182-203. Basingstoke: Palgrave Macmillan.

Lefevere, André. 1977. Translating Literature: The German Tradition from Luther to Rosenzweig. Assen: Van Gorcum.

Malmkjær, Kirsten. 2010. "The Nature, Place and Role of a Philosophy of Translation in Translation Studies." In Translation: Theory and Practice in Dialogue, edited by Rebecca Hyde Parker, Karla L. Guadarrama Garcia and Antoinette Fawcett, 201-18. London and New York: Continuum.

—. 2015. "Schleiermacher's Metaphor." In Friedrich Schleiermacher and the Question of Translation, edited by Larisa Cercel and Adriana Şerban, 185-96. Berlin and New York: de Gruyter.

Nietzsche, Friedrich. 1995- . Complete Works of Friedrich Nietzsche. 19 vols. Edited by Alan D. Schrift and Duncan Large. Stanford, CA: Stanford University Press. 
—. 1998. Twilight of the Idols, or How to Philosophize with a Hammer. Translated by Duncan Large. Oxford and New York: Oxford University Press.

—. 2007. Ecce Homo, or How to Become What You Are. Translated by Duncan Large. Oxford and New York: Oxford University Press.

Pym, Anthony, and Horst Turk. 1998. "Translatability.” In Routledge Encyclopedia of Translation Studies, edited by Mona Baker, 273-77. London and New York: Routledge.

Ricœur, Paul. 2006. On Translation. Translated by Eileen Brennan. London and New York: Routledge.

Sallis, John. 2002. On Translation. Bloomington and Indianapolis: Indiana University Press.

Schleiermacher, Friedrich. 2012 [1813]. "On the Different Methods of Translating." Translated by Susan Bernofsky. In Venuti 2012, 43-63.

Steiner, George. 1998. After Babel: Aspects of Language and Translation. 3rd edition. Oxford: Oxford University Press.

Störig, Hans Joachim, ed. 1963. Das Problem des Übersetzens. Darmstadt: Wissenschaftliche Buchgesellschaft. 
Venuti, Lawrence, ed. 2012. The Translation Studies Reader. 3rd edition. London and New York: Routledge.

— - ed. 2017. Teaching Translation: Programs, Courses, Pedagogies. London and New York: Routledge.

Weber, Max. 2001 [1930]. The Protestant Ethic and the Spirit of Capitalism. Translated by Talcott Parsons. London and New York: Routledge. 